\title{
Seasonal forecasting of fire over Kalimantan, Indonesia
}

\author{
A. C. Spessa ${ }^{1,10}$, R. D. Field ${ }^{2,3}$, F. Pappenberger ${ }^{4,5,6}$, A. Langner $^{7}$, S. Englhart $^{8}$, U. Weber ${ }^{9}$, T. Stockdale ${ }^{4}$, \\ F. Siegert ${ }^{8,13}$, J. W. Kaiser ${ }^{4,10,11}$, and J. Moore ${ }^{12}$ \\ ${ }^{1}$ Department Environment, Earth \& Ecosystems, Open University, Milton Keynes, UK \\ ${ }^{2}$ Department Applied Physics \& Applied Mathematics, Columbia University, New York, USA \\ ${ }^{3}$ NASA Goddard Institute for Space Studies, New York, USA \\ ${ }^{4}$ European Centre for Medium-Range Weather Forecasts, Reading, UK \\ ${ }^{5}$ School of Geographical Sciences, University of Bristol, Bristol, UK \\ ${ }^{6}$ College of Hydrology and Water Resources, Hohai University, Nanjing, China \\ ${ }^{7}$ Forest Resources \& Climate Unit, Institute for Environment \& Sustainability, EC-Joint Research Centre, Ispra, Italy \\ ${ }^{8}$ Remote Sensing Solutions GmbH, Munich, Germany \\ ${ }^{9}$ Department Biogeochemical Integration, Max Planck Institute for Biogeochemistry, Jena, Germany \\ ${ }^{10}$ Department Atmospheric Chemistry, Max Planck Institute for Chemistry, Mainz, Germany \\ ${ }^{11}$ Department of Geography, King's College London, London, UK \\ ${ }^{12}$ College of Engineering, Mathematics \& Physical Sciences, Exeter University, Exeter, UK \\ ${ }^{13}$ GeoBio Center, Ludwigs-Maximilians-University, Munich, Germany \\ Correspondence to: A. C. Spessa (allan.spessa@open.ac.uk)
}

Received: 22 July 2014 - Published in Nat. Hazards Earth Syst. Sci. Discuss.: 6 August 2014

Revised: 10 January 2015 - Accepted: 24 January 2015 - Published: 6 March 2015

\begin{abstract}
Large-scale fires occur frequently across Indonesia, particularly in the southern region of Kalimantan and eastern Sumatra. They have considerable impacts on carbon emissions, haze production, biodiversity, health, and economic activities.

In this study, we demonstrate that severe fire and haze events in Indonesia can generally be predicted months in advance using predictions of seasonal rainfall from the ECMWF System 4 coupled ocean-atmosphere model. Based on analyses of long, up-to-date series observations on burnt area, rainfall, and tree cover, we demonstrate that fire activity is negatively correlated with rainfall and is positively associated with deforestation in Indonesia. There is a contrast between the southern region of Kalimantan (high fire activity, high tree cover loss, and strong non-linear correlation between observed rainfall and fire) and the central region of Kalimantan (low fire activity, low tree cover loss, and weak, non-linear correlation between observed rainfall and fire).

The ECMWF seasonal forecast provides skilled forecasts of burnt and fire-affected area with several months lead time explaining at least $70 \%$ of the variance between rainfall and burnt and fire-affected area. Results are strongly influenced
\end{abstract}

by El Niño years which show a consistent positive bias. Overall, our findings point to a high potential for using a more physical-based method for predicting fires with several months lead time in the tropics rather than one based on indexes only. We argue that seasonal precipitation forecasts should be central to Indonesia's evolving fire management policy.

\section{Introduction}

The rainforests of equatorial Southeast (SE) Asia comprise some of the largest, oldest, most biodiverse forests on the planet (Page et al., 2011). Indonesian forests and peatlands are globally one of the largest reservoirs of terrestrial organic carbon, with an estimated $14 \mathrm{Gt}$ of above-ground carbon in forests (Saatchi et al., 2011) and around $60 \mathrm{Gt}$ of carbon in the below-ground biomass of peatlands (Page et al., 2011). While fires in Indonesia have occurred throughout palaeohistory, their frequency before the 1960s was comparatively rare, coinciding with exceptional but relatively infrequent droughts mostly associated with strong El Niño events (Field 
et al., 2009). The El Niño Southern Oscillation (ENSO) is the major driver of rainfall variability in the equatorial $\mathrm{Pa}$ cific region, and occurs irregularly on a 2-7 year intervals lasting about one year but with varying strengths (Aldrian and Dwi Susanto, 2003; Dobles-Reyes et al., 2013). During the warm ENSO phase (El Niño) sea surface temperatures (SSTs) in the western Pacific tend to be cooler than normal, leading to below-normal dry-season rainfall and extended dry-season length, which increase the risk of mainly degraded forest areas becoming dry enough to burn (Siegert et al., 2001). Large-scale rainfall patterns in the region are also affected by other major weather systems such as the Indian Ocean Dipole (IOD) and the Madden Julian Oscillation (MJO), but their interactions with ENSO are highly complex (Field et al., 2009; Reid et al., 2012; Dobles-Reyes et al., 2013). Furthermore, land rainfall in the maritime continent is also affected by a complex of biophysical effects including land-sea distribution, orography, land cover, and local SSTs (Aldrian and Dwi Susanto, 2003).

Since the early 1960s, however, large-scale fires and related widespread emissions episodes have occurred more frequently across Indonesia, particularly in the southern region of Kalimantan and eastern Sumatra (Field and Shen, 2008; Field et al., 2009; Schultz et al., 2008). These episodes are nearly always associated with El Niño events; for example, emissions from biomass burning in Kalimantan were as much as 30 times greater during 2006, an El Niño year, than during 2000, a wet La Niña year (van der Werf et al., 2008). Furthermore, the destructive fires in Indonesia during the exceptionally strong El Niño in late 1997 and early 1998 rank as some of the largest peak emissions events in recorded history. Past studies estimate about $1 \mathrm{Gt}$ of carbon was released to the atmosphere from the Indonesian fires in 1997, which were mostly concentrated in carbon-rich forested peatlands of the southern region of Kalimantan. This amount was equivalent to over $10 \%$ of the average global annual fossil fuel emissions released during the 1990s (Page et al., 2002; Schultz et al., 2008; van der Werf et al., 2010).

Over the past couple of decades, Indonesia has experienced some of the world's highest rates of deforestation and forest degradation, principally due to fire (Langner et al., 2007; Langner and Siegert, 2009; Hoscilo et al., 2011; Miettinen et al., 2011; Page et al., 2011; Hooijer et al., 2012). The general consensus is that the relatively low fire frequency prior to the 1960s in Indonesia and the relatively higher fire frequency post-1960s are due not to any significant step-up in drought frequency per se but rather to an increase in humancaused ignitions associated with expansion of agriculture, palm and pulp paper plantations, industrial deforestation, and peat forest reclamation. Land use activities such as these make extensive use of fire to clear forest, especially during droughts where the impact of fire is maximised. The activities generally started in Indonesia during the 1960s and intensified greatly in the early 1990s, as exemplified by the transmigrasi projects including the ill-fated Mega Rice project in the southern region of Kalimantan and subsequent peat reclamation projects in that region (Langner et al., 2007; Langner and Siegert, 2009; Hoscilo et al., 2011; Miettinen et al., 2011; Page et al., 2011; Hooijer et al., 2012).

A clear negative correlation between fire activity and antecedent rainfall in Indonesia has been established based on earth observation (EO) fire activity data (Field and Shen, 2008; van der Werf et al., 2008) or proxies of fire activity such as aerosols (Sudiana et al., 2003), haze (Field et al., 2004; Wang et al., 2004; Field et al., 2009), and midtropospheric CO (Nasser et al., 2009). Several studies have demonstrated a clear positive correlation between the fire activity and various indexes of El Niño strength (Fuller and Murphy, 2006; Reid et al., 2012; Wooster et al., 2012). Reid et al. (2012) also discussed the various possible contributions of the ENSO, IOD, and MJO to fire occurrence over western Indonesia during 2000-2010, concluding that, while ENSO is the largest factor influencing fire occurrence, the ENSO Modoki (modified ENSO) and the IOD are also important. Due to the strong influence of ENSO on rainfall patterns across Indonesia, Wooster et al. (2012) demonstrated that statistical forecasting of the extent and magnitude of fire activity a few months in advance based on ENSO indexes is possible. Chen et al. (2011) developed an empirical model to forecast regional fire-season severity with lead times of 3 to 5 months in Amazonia based on a composite index derived from the Oceanic Niño Index and the Atlantic Multi-decadal Oscillation index.

Recent advances in seasonal climate forecasting based on the use of state-of-the-art dynamical models that couple atmosphere, ocean, and land processes and assimilate a vast range of climate-related EO measurements (e.g. sea surface temperatures) (Doblas-Reyes et al., 2013) opens up the possibility of forming a more physical-based method for predicting fires with several months lead time in the tropics, rather than one based on indexes only. The purpose of this study is to determine whether severe fire and haze events in Indonesia can be predicted in advance using one such system, the European Centre for Medium Weather Forecasting (ECMWF) seasonal forecast system (System 4) (Molteni et al., 2011).

Ensemble seasonal climate forecasts issued with several months lead time is a well-established field, and these forecasts have been applied broadly, including to manage and assess risks in agricultural production (Hansen et al., 2011), malaria outbreaks (Jones and Morse, 2010), heatwaves (Lass et al., 2013), flooding, and droughts (Pappenberger et al., 2011, 2013). Comparatively less work has been done on seasonal forecasting of fires, however. The USA has a longstanding seasonal fire-danger prediction system (Roads et al., 2005, 2010), which is based on the National Center for Environmental Prediction's Coupled Forecast System (NCEPCFS) (Saha et al., 2006, 2014). The latest version of the NCEP-CFS generates global and regional spectral model ensemble forecasts over a 3-7-month period, which in turn provides required input meteorological variables for calculating 
fire-danger indexes based on the National Fire Danger Rating System (Cohen and Deeming, 1985; Burgan, 1988). Roads et al. (2010) demonstrated the seasonal forecasts of fire-danger indexes driven by NCEP-CFS outputs had skill in predicting fire activity across western USA. The European Forest Fire Information System (McInerney et al., 2013) currently provides temperature and rainfall anomalies that are expected to exist over European and Mediterranean areas during the next 2 months based on the multi-member ECMWF System 4 seasonal forecast system. Areas that are drier and hotter than normal indicate higher forest-fire danger (http://forest.jrc.ec. europa.eu/effis/applications/long-term-forecast/).

Since no equivalent seasonal fire forecasting system exists for Indonesia, we were motivated to develop and test one for the severely fire-affected region of southern Kalimantan as a case study, based on 7-month forecasts of monthly rainfall from the ECMWF System 4 for the period 19972010. The case study was identified from a comparison of observed burnt area and tree cover patterns across a broader region of southern-central Kalimantan, which generally exhibits a June-November dry season (Aldrian and Dwi Susanto, 2003). We evaluated the skill of the seasonal rainfall forecasts against observed rainfall and in predicting observed burnt area and fire-affected area. We further assessed forecast skill by analysing observed burnt area and fire-affected area in relation to observed rainfall. Several previous studies have focused on the highly non-linear nature of precipitation and fire occurrence in the region; severe fire happens only below a threshold of seasonal precipitation (Field et al., 2004, 2009; van der Werf et al., 2008; Field and Shen, 2008). It is only during years with a sufficiently strong precipitation deficit that disturbed peatlands can dry to the point of ignition and burn. In a practical sense, therefore, seasonal fire forecasting entails determining whether this threshold will be crossed during the upcoming dry season.

\section{Methods}

In order to understand and assess seasonal forecast skill, our analyses proceeded in two stages. We first determined the strength of precipitation-fire relationships over the region of southern-central Kalimantan for our 1997-2010 analysis period, knowing a priori that these relationships have been identified in other and earlier versions of the data used. We then evaluated the forecast skill of System 4 , focusing on the degree to which the model could separate the precipitation associated with normal and severe fire years.

\subsection{Study area and study periods}

Borneo is divided among three countries: Indonesia, Malaysia, and Brunei (Fig. 1). The broader region of southern-central Kalimantan (Indonesia) (Fig. 1) matches approximately the only region of Borneo identified by Aldrian and Dwi Susanto (2003) as having, on the average, a June to November dry season. Preliminary analyses of available data on burnt area data and fire-affected area (see below) revealed that over $95 \%$ of fires occurred during this period.

During our study period, 1997-2010, El Niño events were registered in 1997-1998, 2002, 2004, 2006, and 2009 (http://www.cpc.noaa.gov/products/analysis_monitoring/ ensostuff/ensoyears.shtml). However, drought and associated fires during the 1998 phase of the 1997-1998 El Niño event were concentrated in east Kalimantan (Siegert et al., 2001; Field et al., 2004), which does not display as clearly defined wet and dry seasons (Aldrian and Dwi Susanto, 2003). Analyses of the Global Precipitation Climatology Project (GPCP) rainfall data (see below) confirmed 1998 as a non-drought year for the southern-central region of Kalimantan. For the purposes of this paper, therefore, we regard 1997, 2002, 2004, 2006, and 2009 as El Niño years, but not 1998 .

\subsection{Fire data}

To increase the robustness of our analyses of burnt area and fire-affected area in relation to rainfall and forest cover change, we used two independent monthly satellite-based fire data sets spanning 1997-2010, aggregated to $0.5^{\circ}$ grid cells. Some fires may miss being counted by remote sensing because they may be too small or start and finish outside the satellite overpass. We used satellite data because they remain the best source of fire data in regions such as Kalimantan, where consistent, verifiable ground-based fire data are not available. The first data set is from the Global Fire and Emissions Database version 4 (GFED4) (Giglio et al., 2013), and the second is from the Remote Sensing Solutions (RSS) GmbH (after Langner and Siegert, 2009, with unpublished updates from RSS GmbH).

The GFED4 burnt area is available at a monthly time step at $0.25^{\circ}$ resolution and is based on active fire detection from European Remote Sensing Satellite Along-Track Scanning Radiometer (ATSR) World Fire Atlas, Tropical Rainfall Measuring Mission Visible and Infrared Scanner (VIRS), and the Moderate Resolution Imaging Spectroradiometer (MODIS) burnt area product (MCD64A1) (Giglio et al., 2013). For the MODIS era (2000 to present), the GFED4 monthly burnt area data set was derived exclusively from the $500 \mathrm{~m}$ MCD64A1 burnt area product (Giglio et al., 2013). For the pre-MODIS era, burnt area was derived from calibrating monthly active fire counts from the VIRS and ATSR sensors to monthly burnt area supplied by the MCD64A1 product which was modified according to Giglio et al. (2010).

RSS fire-affected area data are only available for Borneo and are based on active fire detections derived from National Oceanic and Atmospheric Administration (NOAA) Advanced Very High Resolution Radiometer (AVHRR), ATSR, and MODIS imagery (Langner and Siegert, 2009). Fires be- 

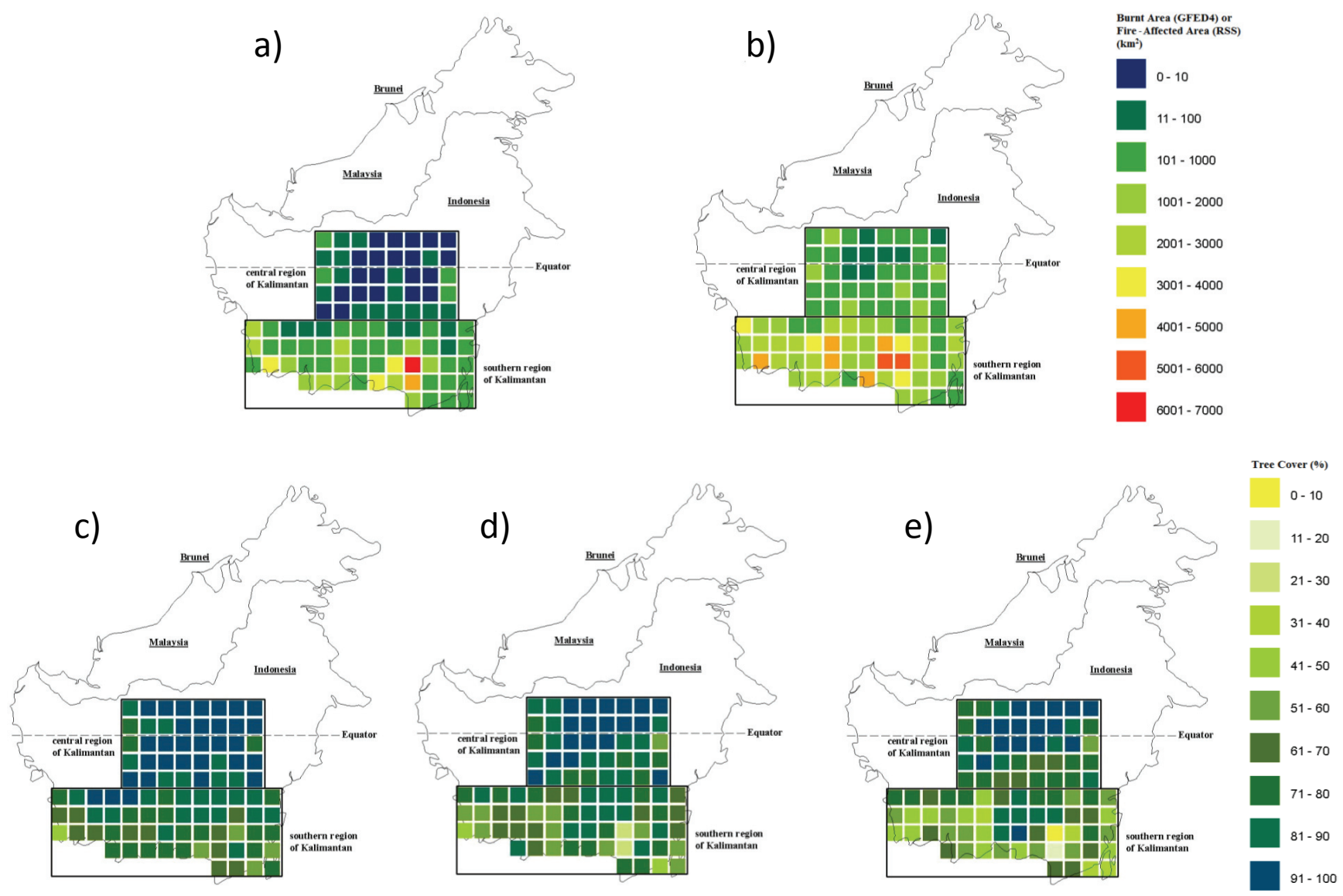

Figure 1. The island of Borneo showing burnt and fire-affected area (top) and tree cover patterns (bottom) across the southern-central region of Kalimantan: (a) total GFED4 burnt area, (b) total RSS fire-affected area, (c) mean 1993 tree cover, (d) mean 1997 tree cover, and (e) mean 2010 tree cover. Data are plotted at $0.5^{\circ}$ grid-cell resolution. Number of $0.5^{\circ}$ grid cells in southern Kalimantan is 53 . Number of $0.5^{\circ}$ grid cells in southern Kalimantan is 40 .

fore 2002 were derived from hotspots recorded by NOAA 14 and ATSR by adding their data sets. ATSR was used in addition to NOAA because, especially in 1997 and 1998, several large fires were not recorded by NOAA due to operation errors at the receiving station. Fires from 2002 onwards were derived from MODIS hotspots (MOD14/MYD14). One single hotspot pixel (sensor element) represents the area of the corresponding sensor resolution of $1 \mathrm{~km}$. This pixel can be affected by a single fire or more than one fire (Langner and Siegert, 2009). Following the convention of Langner and Siegert (2009), we define the RSS data as fire-affected area rather than burnt area because the actual size of the burnt area is unknown and strongly relates to the underlying land cover type. However, taking into account the possible combination of very hot sub-pixel fires and larger and/or reoccurring fires that result in overlapping hotspot areas, which are considered only once within each year, we assume that every hotspot pixel detected by the satellite is regarded as completely affected by fire. Even though different satellite systems with various temporal resolutions (number of overpasses per $24 \mathrm{~h}$ ) have been used to derive the RSS data set,
Langner and Siegert (2009) concluded that the consistency over the whole data set is sufficiently high when working with fire-affected areas instead of active fire numbers.

\subsection{Forest cover data}

Our analyses are based on three tree cover products: the global AVHRR 1993 continuous percentage tree cover product available at $1 \mathrm{~km}$ (DeFries et al., 2000) and two MODIS tree cover products available for SE Asia at $500 \mathrm{~m}$ for the years 2000 and 2010 (Miettinen et al., 2011).

\subsection{Rainfall data}

Version 1.2 of the GPCP one-degree daily (1DD) rainfall data formed the basis for comparing burnt and fire-affected areas in relation to observed rainfall and evaluating seasonal rainfall forecasts from System 4 . The data set is a global product available at a $1^{\circ}$ resolution and combines precipitation estimates from several sources, including infrared and passive 
microwave rain estimates and rain gauge observations (Adler et al., 2003; Huffman et al., 2009).

\subsection{ECMWF seasonal forecast system (System 4)}

Seasonal predictions of rainfall were derived from the ECMWF Seasonal forecast System (System 4), which provides operational seasonal predictions (Molteni et al., 2011). System 4 is the most recent ECMWF seasonal forecast system and includes 51 member ensembles and consists of 7-month forecasts initialised on the first day of every month. The seasonal forecast has a resolution of $\sim 79 \mathrm{~km}$ (T255L91). It is coupled with an ocean model with a horizontal resolution of $1^{\circ}$. Singular vectors and an ensemble of ocean analysis, including SSTs, provide the initial perturbations. Atmospheric model uncertainties are included through a three-time-level stochastically perturbed parameterized tendency scheme and the stochastic back-scatter scheme, which is similar to the ECMWF medium-range forecasting system. The operational seasonal forecasts are accompanied by a hindcast system which covers a 30-year period (from 1981 to today) where the land surface is initialised using an offline simulation driven by ERAInterim data (Dee et al., 2011). The hindcast usually has 15 ensemble members. Molteni et al. (2011) presented an overview of S4 model biases and forecast performance.

We restricted our use of the ECMWF System 4 rainfall forecasts to 1 May initialisations, i.e. seasonal forecasts spanning 1 May to 30 November, each year from 1997 to 2010. Mean daily rainfall for each month and each ensemble member was calculated.

\subsection{Data preparation and statistical analyses}

We aggregated the burnt area data (GFED4), the fire-affected area data (RSS), and the tree cover data (1993, 2002, and 2010 ) to $0.5^{\circ}$ grid cells and down-scaled the GPCP data to $0.5^{\circ}$ grid cells by linear interpolation.

Total area burnt (GFED4) and total fire-affected area (RSS) were calculated for each $0.5^{\circ}$ grid cell in the southerncentral region of Kalimantan by summing the respective monthly burnt areas between June and November, 19972010. Since a 1997 tree cover product does not exist for the study area, we derived a 1997 tree cover data set based on simple linear interpolation between 1993 and 2000 tree covers. Spatial plots of total fire-affected area (RSS) and total area burnt (GFED4) were then visually compared to spatial plots of tree cover in 1993, 1997, and 2010 at $0.5^{\circ}$ resolution.

For the central and southern regions of Kalimantan and each year, seasonal mean GFED4 burnt area per grid cell and seasonal mean RSS fire-affected area per grid cell were calculated by firstly summing the respective monthly burnt areas or fire-affected areas between June and November for each $0.5^{\circ}$ grid cell, secondly summing these values over all grid cells, and finally dividing by the number of grid cells. The range of each seasonal mean burnt area per grid cell or fireaffected area per grid cell was calculated as $\pm 1.96 \times \mathrm{SE}_{\text {mean }}$. This is similar to previous studies using seasonal (van der Werf et al., 2008; Wooster et al., 2012) or monthly mean (Wang et al., 2004; Field and Shen, 2008; Field et al., 2009) estimates of fire activity or haze at an island scale.

For the central and southern regions of Kalimantan and each year, seasonal mean GPCP rainfall per grid cell was calculated by taking the average of the daily mean rainfall per month values between June and November for each $0.5^{\circ}$ grid cell, then summing these values over all grid cells, and finally dividing by the number of grid cells. The range of each seasonal mean GPCP rainfall per grid cell was calculated as $\pm 1.96 \times \mathrm{SE}_{\text {mean }}$.

For the southern region of Kalimantan only and each year, seasonal mean System 4 rainfall per grid cell was calculated by restricting the System 4 outputs to the middle-ranked 17 members of the 51 member ensemble (middle tercile), then averaging over the mean daily rainfall per month values between June and November for each System 4 grid cell, then summing these values over all grid cells, and finally dividing by the number of grid cells. The mean of the highest-ranked 17 members of the 51 member System 4 ensemble (upper tercile) and the mean of the lowest-ranked 17 members of the 51 member System 4 ensemble (lower tercile) were calculated similarly. The upper range for each year was defined as mean $_{\text {upper tercile }}-$ mean $_{\text {middle tercile, and the lower range for }}$ each year was defined as mean $n_{\text {middle tercile }}-$ mean $_{\text {lower tercile }}$.

The following statistical analyses were undertaken:

- correlation between seasonal mean GFED4 burnt area per grid cell and seasonal mean RSS fire-affected area per grid cell;

- regression of seasonal mean GFED4 burnt area per grid cell on seasonal mean GPCP rainfall per grid cell for the central and southern regions of Kalimantan;

- regression of seasonal mean RSS fire-affected area per grid cell on seasonal mean GPCP rainfall per grid cell for the central and southern regions of Kalimantan;

- regression of seasonal mean GFED4 burnt area per grid cell on seasonal mean System 4 rainfall per grid cell for the southern region of Kalimantan;

- regression of seasonal mean RSS fire-affected area per grid cell on seasonal mean System 4 rainfall per grid cell for the southern region of Kalimantan; and

- correlation between seasonal mean GPCP rainfall per grid cell and seasonal mean System 4 rainfall per grid cell for the southern region of Kalimantan.

Each regression analysis comprised two parts: linear regression of the form $Y=a+b \times X$ and non-linear regression of the form $Y=a+b \times \ln (X)$, where $Y$ is seasonal mean burnt 
Table 1. Summary statistics for burnt and fire-affected area and tree cover in the southern and central regions of Kalimantan. Values shown are mean $\pm 1.96 \times \mathrm{SE}_{\text {mean }}$. Number of grid cells in the southern region is 53 . Number of grid cells in the central region is 40. Grid cell resolution is $0.5^{\circ}$.

\begin{tabular}{|c|c|c|}
\hline & $\begin{array}{l}\text { Southern region of } \\
\text { Kalimantan }\end{array}$ & $\begin{array}{l}\text { Central region of } \\
\text { Kalimantan }\end{array}$ \\
\hline $\begin{array}{l}\text { Seasonal mean GFED4 burnt } \\
\text { area per grid cell (averaged } \\
\text { over 1997-2010) }\left(\mathrm{km}^{2}\right)\end{array}$ & $81.3 \pm 15.0$ & $3 \pm 1.3$ \\
\hline $\begin{array}{l}\text { Seasonal mean RSS fire- } \\
\text { affected area per grid cell } \\
(\text { averaged over 1997-2010) } \\
\left(\mathrm{km}^{2}\right)\end{array}$ & $146.9 \pm 15.0$ & $35.1 \pm 5.7$ \\
\hline $\begin{array}{l}\text { Mean tree cover per grid } \\
\text { cell } 1993(\%)\end{array}$ & $76.0 \pm 1.5$ & $92.4 \pm 0.9$ \\
\hline $\begin{array}{l}\text { Mean tree cover per grid } \\
\text { cell } 1997(\%)\end{array}$ & $68.3 \pm 2.0$ & $87.6 \pm 1.4$ \\
\hline $\begin{array}{l}\text { Mean tree cover per grid } \\
\text { cell } 2010(\%)\end{array}$ & $58.1 \pm 2.5$ & $84.2 \pm 1.8$ \\
\hline $\begin{array}{l}\text { Seasonal mean GFED4 burnt } \\
\text { area per grid cell }(1997)\left(\mathrm{km}^{2}\right)\end{array}$ & $363.1 \pm 54.5$ & $9.5 \pm 4.4$ \\
\hline $\begin{array}{l}\text { Seasonal mean RSS fire- } \\
\text { affected area per grid cell (1997) } \\
\left(\mathrm{km}^{2}\right)\end{array}$ & $514.5 \pm 52.8$ & $96.5 \pm 13.9$ \\
\hline $\begin{array}{l}\text { Seasonal mean GFED4 burnt } \\
\text { area per grid cell (averaged } \\
\text { over El Niño years } 2002 \text {, } \\
2004,2006,2009)\left(\mathrm{km}^{2}\right)\end{array}$ & $155.6 \pm 34.7$ & $5.7 \pm 2.8$ \\
\hline $\begin{array}{l}\text { Seasonal mean RSS fire- } \\
\text { affected area per grid cell } \\
\text { (averaged over El Niño years } \\
2002,2004,2006,2009)\left(\mathrm{km}^{2}\right)\end{array}$ & $291.5 \pm 31.7$ & $54.5 \pm 9.2$ \\
\hline
\end{tabular}

area per grid cell (GFED4) or seasonal mean fire-affected area per grid cell (RSS), $X$ is seasonal mean daily rainfall per grid cell (GPCP or System 4), and ln is the natural $\log$ transformation.

\section{Results}

\subsection{Fire activity vs. tree cover change}

Fire activity and tree cover loss were clearly both much higher across a distinct southern region of Kalimantan $(N=$ 53 grid cells at $0.5^{\circ}$ resolution) compared with a central region of Kalimantan immediately above it $(N=40$ grid cells at $0.5^{\circ}$ resolution) (Fig. 1). Seasonal mean GFED4 area burnt in the south was, on the average, 27.1 times higher than in the central region (Table 1); seasonal mean RSS fire-affected area in southern region was, on the average, 4.2 times higher than in the central region (Table 1). In the southern region, the mean tree cover in 2010 was $17.9 \%$ lower than that in 1993 and $10.2 \%$ lower than that in 1997 (Table 1). In the central region, the mean tree cover in 2010 was $8.2 \%$ lower than that in 1993 and $4.4 \%$ lower than that in 1997 (Table 1).

\subsection{RSS fire-affected area vs. GFED4 burnt area}

Seasonal mean RSS fire-affected area and seasonal mean GFED4 burnt area was highly correlated in the southern region $\left(R^{2}=0.96\right)$ and the central region $\left(R^{2}=0.88\right)$. Through the years in which El Niño affected the centralsouthern region (1997, 2002, 2003, 2004, 2006, and 2009), seasonal mean RSS fire-affected area was consistently much higher than seasonal mean GFED4 burnt area. In 1997 (preMODIS), seasonal mean RSS fire-affected area was 1.9 times higher than seasonal mean GFED4 burnt area in the south and 10.2 times higher than the equivalent for GFED4 in the central region (Table 1). Averaged across the other El Niñoaffected years (all post-MODIS), RSS fire-affected area was 1.4 times higher than seasonal mean GFED4 burnt area in the south and 9.6 times higher than the equivalent for GFED4 in the central region (Table 1).

\subsection{Burnt and fire-affected area vs. observed rainfall}

Seasonal mean burnt and fire-affected area was non-linearly and highly correlated with seasonal mean GPCP rainfall for the GFED4 data set (southern region: $R^{2}=0.86$; central region: $R^{2}=0.80$; Fig. 2a, $\mathrm{b}$ ) and for the RSS data set (southern region: $R^{2}=0.90$; central region: $R^{2}=0.70$; Fig. $3 \mathrm{a}, \mathrm{b}$ ). For the GFED4 data set, the magnitude of the slopes and the intercepts determining the non-linear relationships were respectively 29.8 and 27.2 times greater for the southern region than the central region (Fig. 2a, b). For the RSS data set, the magnitude of the slopes and the intercepts determining the non-linear relationships were respectively 5.2 and 4.6 times greater for the southern than in the central region (Fig. 3a, b). For the southern region, we diagnosed a clear rainfall threshold approximately equal to $6 \mathrm{~mm}$, above which fire activity was almost negligible and below which it increased exponentially (Figs. 2b, 3b).

\subsection{Burnt and fire-affected area vs. System 4 rainfall}

Focusing on the southern region, seasonal mean burnt and fire-affected area was non-linearly and significantly correlated with seasonal mean daily System 4 rainfall for the RSS data set $\left(R^{2}=0.70\right)$ (Fig. 4a) and the GFED4 data set $\left(R^{2}=0.76\right)$ (Fig. 4b). For each System 4-based relationship, the year 2006 was an obvious outlier. Both System 4-based analyses revealed a similar rainfall threshold approximately equal to $7 \mathrm{~mm}$, but this is less clear-cut compared to the GPCP-based analyses (Fig. 4a, b).

\subsection{System 4 rainfall vs. observed rainfall}

Seasonal mean System 4 rainfall and seasonal mean GPCP rainfall were highly correlated $\left(R^{2}=0.91\right)$, and for each year 
a) southern region of Kalimantan

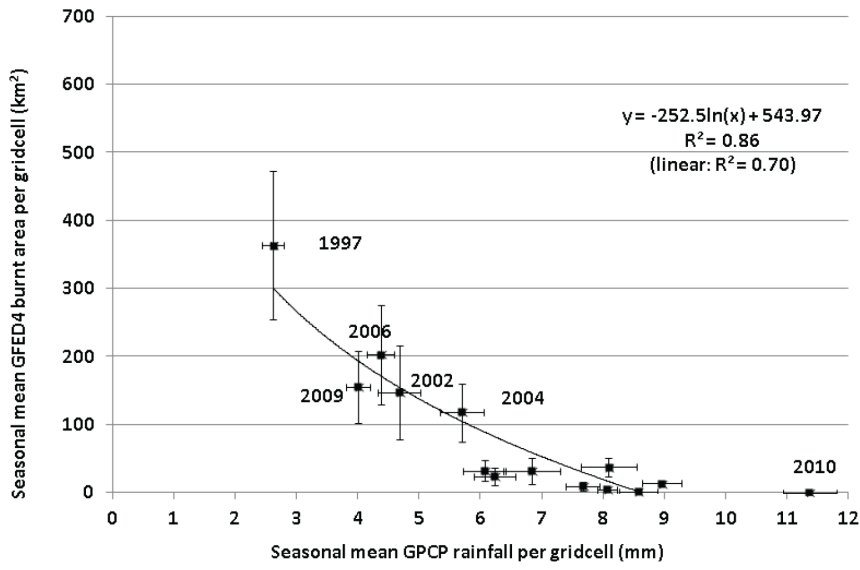

b) central region of Kalimantan

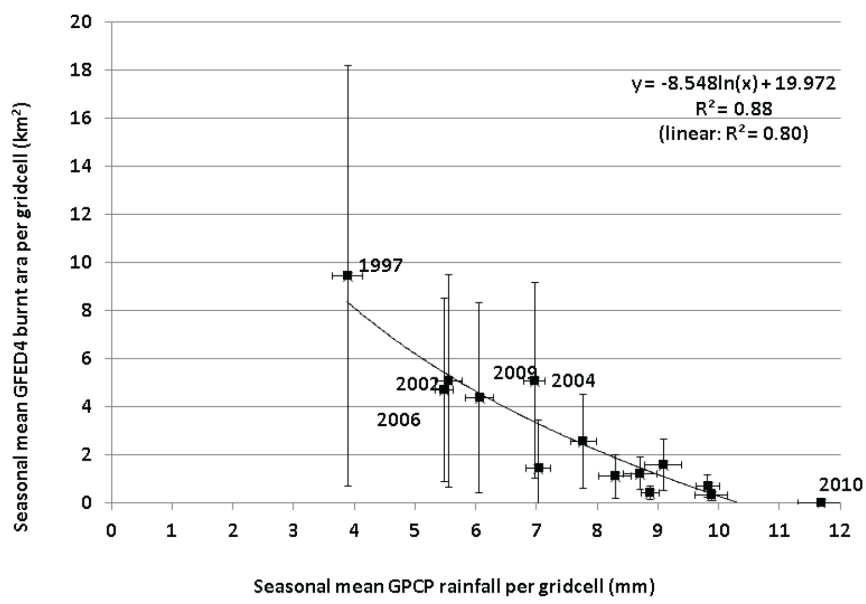

Figure 2. (a) Southern region of Kalimantan: seasonal mean GFED4 burnt area per grid cell as a function of seasonal mean GPCP rainfall per grid cell; and (b) central region of Kalimantan: seasonal mean monthly GFED4 burnt area per grid cell as a function of seasonal mean GPCP rainfall per grid cell. The edges of the whiskers refer to the 5 th and 95 th percentiles $\left( \pm 1.96 \times \mathrm{SE}_{\text {mean }}\right)$.

their respective values overlapped (Fig. 5). Seasonal mean System 4 rainfall was higher than seasonal mean GPCP rainfall during each El Niño-affected year: $1997(+0.19 \mathrm{~mm})$, $2002(+1.46 \mathrm{~mm}), 2004(+0.52 \mathrm{~mm}), 2006(+2.2 \mathrm{~mm})$, and 2009 (+0.88 mm) (Fig. 5).

\subsection{System 4 predicted vs. observed SSTs}

Further analyses of the 15 member ensemble System 4 hindcasts from 1997 to 2010 demonstrated that while most members correctly predicted observed SSTs, 2006 was particularly anomalous (Fig. 6). Only 2 out of 15 members predicted the SST cooling in this year. By contrast, in 1997, when the strongest cooling was observed, 13 out of 15 members predicted a strong cooling (Fig. 6).

\section{Discussion}

\subsection{Observed fire, rainfall, tree cover patterns}

Based on analyses of a comparatively up-to-date and long series observations on burnt and fire-affected area and rainfall (14 years from 1997 to 2010) and tree cover (1993, 1997, 2000 , and 2010), our work supports a large body of work that demonstrates that, for different tropical regions, fire activity is negatively correlated with rainfall and positively associated with deforestation in Indonesia (Langner et al., 2007; van der Werf et al., 2008; Langner and Siegert, 2009; Field et al., 2009), Amazonia (Aragao et al., 2008), and Columbia (Armenteras-Pascual et al., 2011). Our results highlight the stark contrast between the southern region of Kalimantan (high fire activity, high tree cover loss, and strong non-linear correlation between rainfall and fire) and the central region of Kalimantan (low fire activity, low tree cover loss, and weak non-linear correlation between rainfall and fire). The amount of forest cover loss between 1997 and 2010 that we 
a) southern region of Kalimantan

b) central region of Kalimantan
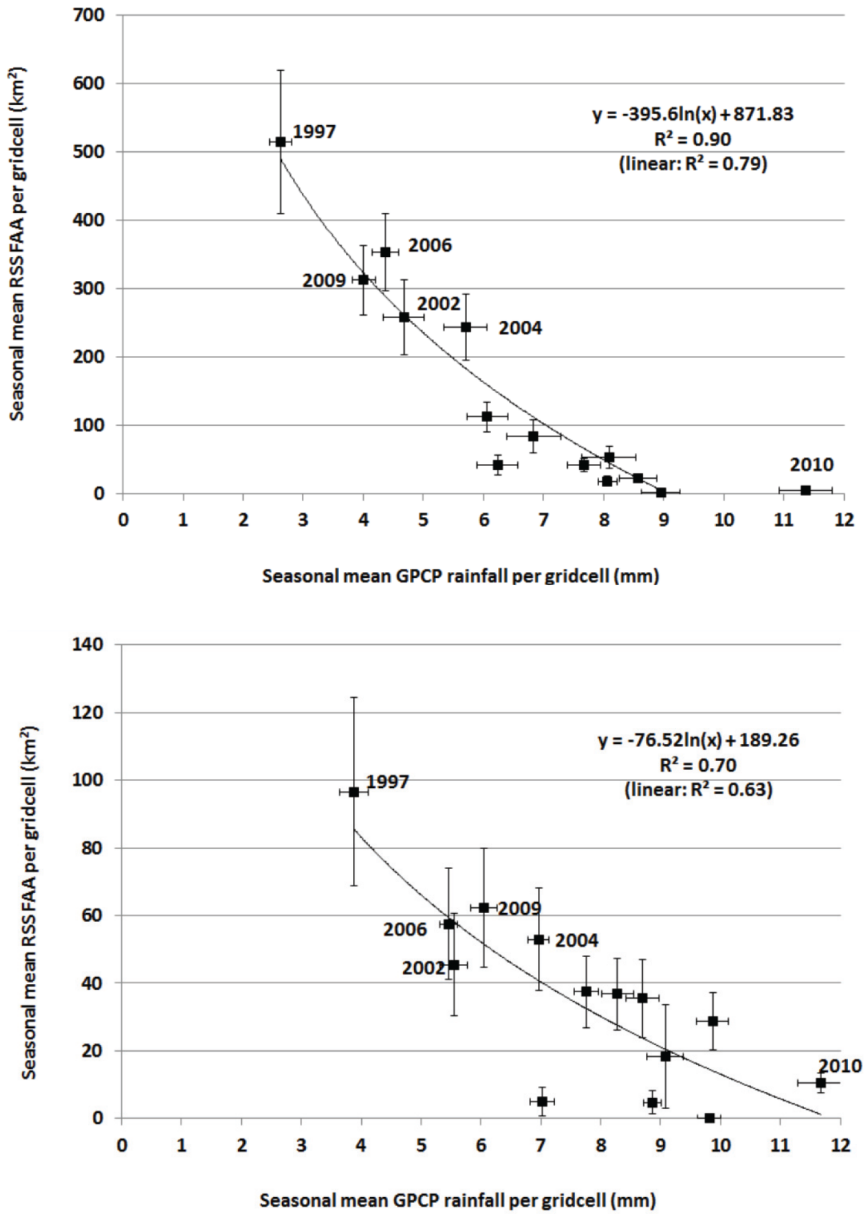

Figure 3. (a) Southern Kalimantan: seasonal mean RSS fire-affected area (FAA) per grid cell as a function of seasonal mean GPCP rainfall per grid cell; (b) central Kalimantan: seasonal mean RSS FAA per grid cell as a function of seasonal mean GPCP rainfall per grid cell. The edges of the whiskers refer to the 5 th and 95 th percentiles $\left( \pm 1.96 \times \mathrm{SE}_{\text {mean }}\right)$.

estimated is likely to be conservative. Forest cover immediately prior to the major El Niño-induced fires of 1997 probably matches more closely forest cover in 1993 than that based on a simple linear interpolation between forest cover in 1993 and 2002. Although fire data covering the 1993 to 1997 period are not available, no major El Niño events occurred during this period, except for a relatively minor event in 1994-1995 (http://www.cpc.noaa.gov/products/analysis_ monitoring/ensostuff/ensoyears.shtml). Our finding of strong non-linear relationships between fire and rainfall for southern Kalimantan confirms similar relationships reported for the region (van der Werf et al., 2008; Field et al., 2009). The exponential increase in fire activity in southern Kalimantan below a moisture threshold of around $6 \mathrm{~mm}$ per day supports the finding of a similar fire moisture threshold for the region (Field et al., 2009).

Our results support the general consensus that while fire activity is strongly linked to drought in Kalimantan, the strength of this relationship is mediated by land use and land cover change and the presence of disturbed peatlands. Nu- merous studies have reported the widespread deliberate use of fire in the southern region of Kalimantan to clear forests to establish plantations (mainly rice, oil palm, and acacia), as well as the widespread incidence of escaped fires associated with these activities and with logging (Langner et al., 2007; van der Werf et al., 2008; Langner and Siegert, 2009). Furthermore, extensive areas of peatland have been drained for plantation establishment, which has led to an increase in fire activity in these areas because drained peats lower the water table, exposing a greater depth of dry peat to burning (Page et al., 2011; Hooijer et al., 2012). By contrast, the central region of Kalimantan has undergone comparatively little development to date (Langner et al., 2007; Langner and Siegert, 2009; Margono et al., 2014). The central region has steep slope sections which reduce the ease of forest exploitation and clearing compared to the relatively flatter terrain of the southern region (Langner and Siegert, 2009). Due to its highly uneven topography, the central region also contains relatively less peat (Page et al., 2011; Hooijer et al., 2012). 
a) southern region of Kalimantan

b) southern region of Kalimantan
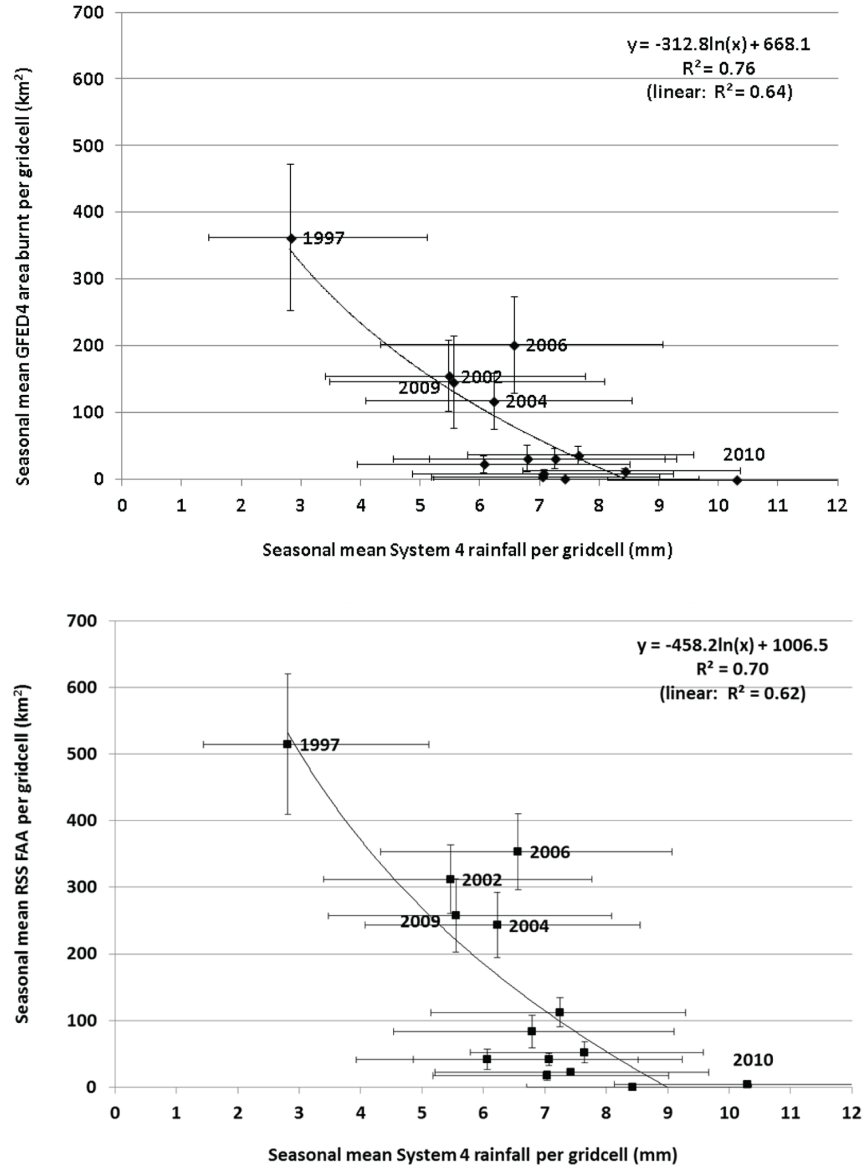

Figure 4. Southern Kalimantan: (a) seasonal mean GFED4 burnt area per grid cell as a function of seasonal mean System 4 rainfall per grid cell; (b) seasonal mean RSS fire-affected area (FAA) per grid cell as a function of seasonal mean System 4 mean rainfall per grid cell. Number of System 4 grid cells in southern Kalimantan is 23. The edges of the burnt and fire-affected area whiskers refer to the 5th and 95th percentiles respectively $\left( \pm 1.96 \times \mathrm{SE}_{\text {mean }}\right)$. The upper edge of the System 4 whiskers is mean $_{\text {upper tercile }}-$ mean $_{\text {middle tercile }}$, and the lower

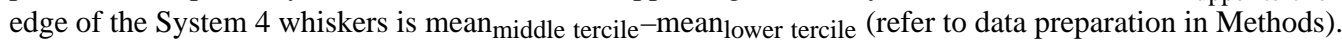

\subsection{Seasonal forecasting of fire}

Based on two independent burnt and fire-affected area data sets, we demonstrated that seasonal forecasts of rainfall from the ECMWF System 4 can predict fire activity during the June-November dry season in the southern region of Kalimantan. The empirical fits between System 4 rainfall and fire activity were highly non-linear, similar to those based on observed rainfall. The correlations between System 4 rainfall and fire activity, while not as good as those between observed rainfall and fire activity, were nonetheless significant (RSS fire-affected area data set: $R^{2}=0.70$; GFED4 burnt area data set: $R^{2}=0.76$ ). These significant relationships between System 4 rainfall and burnt area and between System 4 rainfall and fire-affected area demonstrate a prospective use of System 4 rainfall to predict seasonal fire activity as part of a region-wide fire management programme for the southern region of Kalimantan. Further development of any such programme would need to consider, however, three impor- tant factors potentially affecting the robustness of predicting burnt area as a simple function of modelled rainfall. These factors are (i) a positive rainfall bias in the System 4 model, (ii) biases in the burnt area and fire-affected area data sets used to construct these relationships, and (iii) the influence of land use and land cover change, as well as peat drainage, on rainfall vs. fire relationships for the southern region of Kalimantan.

\subsection{Rainfall bias in seasonal forecast}

Although ECMWF and observed rainfall were well correlated $\left(R^{2}=0.91\right)$, ECMWF rainfall was consistently higher during the El Niño-affected years of 1997, 2002, 2004, 2006, and 2009, i.e. years with high fire activity. Furthermore, this bias was not consistent across these drought years. The smallest positive bias occurred during the strong $1997 \mathrm{El}$ Niño year of $1997(+0.19 \mathrm{~mm})$, and the greatest positive bias occurred during the moderate El Niño year of 2006 


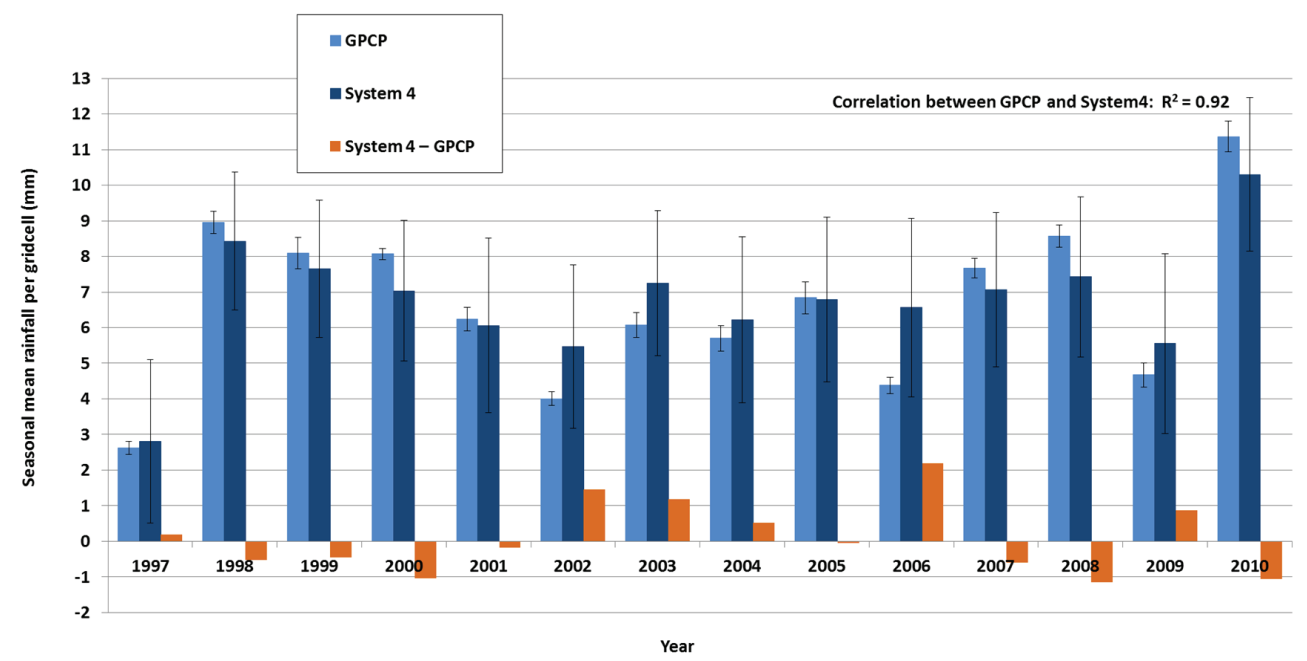

Figure 5. Southern Kalimantan: seasonal mean GPCP rainfall per grid cell vs. seasonal mean System 4 rainfall per grid cell. The edges of the GPCP whiskers refer to the 5th and 95th percentiles $\left( \pm 1.96 \times \mathrm{SE}_{\text {mean }}\right)$. The upper edge of the System 4 data point whiskers is

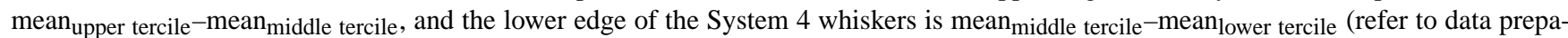
ration in Methods).

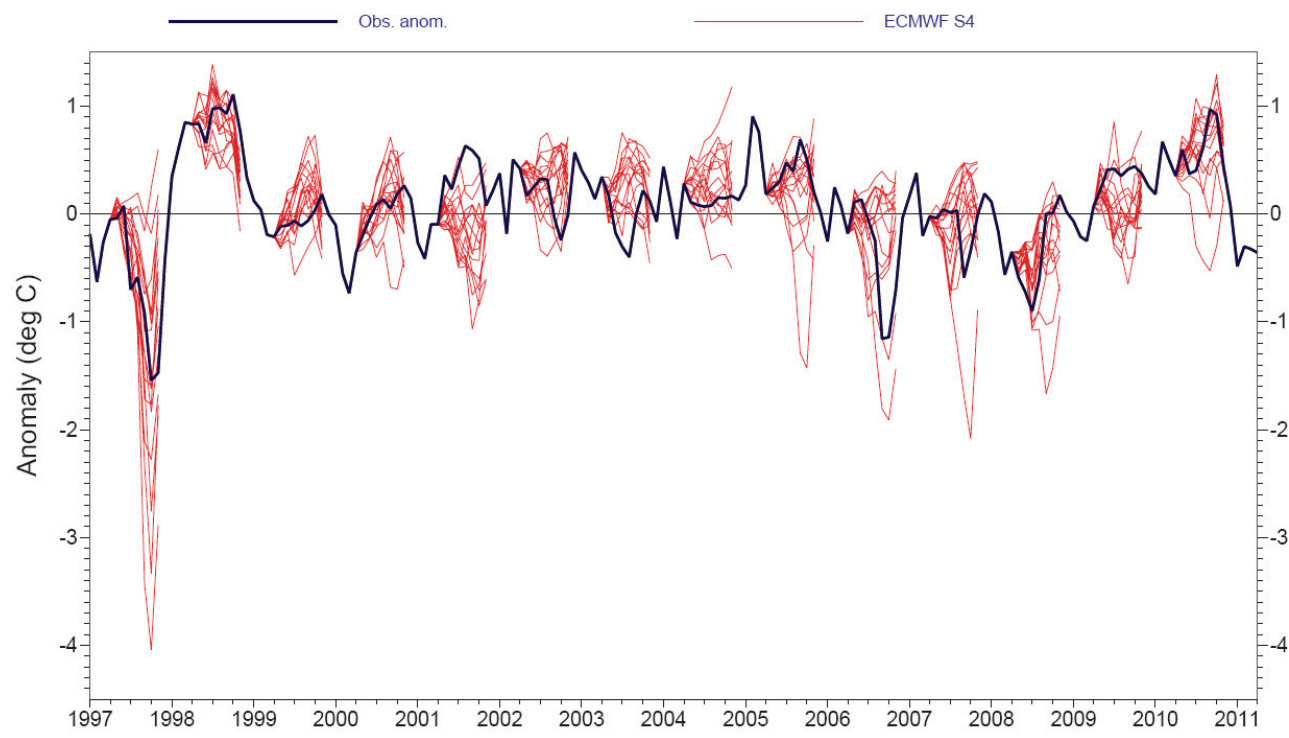

year

Figure 6. System 4 SST anomalies vs. observed SST anomalies over the Indian ocean $\left(0^{\circ}-10^{\circ} \mathrm{S}, 90^{\circ}-110^{\circ} \mathrm{E}\right)$, 1997-2010. In this figure the variance has been corrected to match the variance of the observations. The observed anomalies are derived from ERA Interim and the forecasts shown are based on the S4 hindcast system with 15 ensemble members.

$(+2.2 \mathrm{~mm})$. The latter was clearly an outlier that reduced the goodness-of-fit of the empirical relationships between ECMWF rainfall and fire activity. Although the estimated moisture threshold diagnosed from the ECMWF rainfall vs. fire relationships $(7 \mathrm{~mm})$ was similar to that estimated from the GPCP rainfall vs. fire relationships $(6 \mathrm{~mm})$, it not as clear cut because of the 2006 outlier.
Seasonal predictability in the maritime continent is to a large extent due to the ENSO and the changes in SSTs associated with these oscillations (van Oldenborgh et al., 2005; Lavers et al., 2009; Dobles-Reyes et al., 2013). In general, cooler SSTs indicate below-average rainfall, and warmer SSTs indicate above-average rainfall. Our analyses of SSTs from multi-member System 4 hindcasts covering our study region clearly showed that while most members correctly 
predicted observed SSTs, the worst result was in 2006, for which only $13 \%$ of members predicted the SST cooling. The best was in 1997, for which close to $90 \%$ predicted the SST cooling, corresponding with our observation that the smallest difference in System 4 and GPCP rainfall during any drought year was in 1997 . Whether the relatively poor prediction in 2006 is a consequence of model error, or is simply due to the event having low predictability, is not known. Some variations in SST and rainfall will always be unpredictable, but we do know that model error has the potential to play a role.

Molteni et al. (2011) reported a positive rainfall bias in Indonesia for System 4. They suggested this was consistent with too-strong easterly trade winds simulated by the System 4 atmospheric model in the central and western Pacific, which act to reduce the movement of the western warm pool towards the east Pacific during El Niño onset, hence maintaining warmer-than-expected SSTs in the model for Indonesia. The impact of this bias on the specific 2006 forecast is not known, but it suggests that more work is needed to improve the feedback between SSTs and climate in System 4, with direct benefits for seasonal forecasting of fires in the region.

\subsection{Biases in the burnt area and fire-affected area products}

Although the RSS fire-affected area and GFED4 burnt area data yielded similar patterns (southern region of Kalimantan burning much more than the central region, non-linear relationships between observed rainfall and fire activity and between System 4 rainfall and fire activity), RSS fire-affected area was consistently higher than GFED4 burnt area. During the MODIS era (2000 onwards), GFED4 is based on $500 \mathrm{~m}$ MODIS burnt area product (MDC64A1) (Giglio et al., 2013), and RSS is based on $1 \mathrm{~km}^{2}$ MODIS active fire product (MOD14/MYD14; 2002 onwards) (Langner and Siegert, 2009). Previous work has shown that the MODIS burnt area product tends to underestimate fire activity in the tropics because a 16-day cloud-free mosaic is necessary to map the burnt areas (Roy et al., 2008). By contrast, the RSS data, which are based on active fire detections (hotspots), can lead to an overestimation of the actual burnt area, as a single sensor element can even be saturated by a small-scale (subpixel) fire of high temperature. On the other hand, areas of overlapping hotspots are only counted once per year, leading to an underestimation of the burnt area. In general, the actual burnt area is difficult to predict and much depends on year, season, and vegetation type (Miettinen et al., 2007). Due to these reasons, Langner and Siegert (2009) refer to "fire-affected" instead of "burnt" area and a comparison with other burnt area products requires caution. Pre-MODIS RSS burnt-area data are based on AVHRR 14 and ATSR hotspot data (Langner and Siegert, 2009) and pre-MODIS GFED4 data are based on ATSR and VIRS hotspots with a further correction (Giglio et al., 2010, 2013). For several reasons,
AVHRR generally detects a much higher number of active fire events than ATSR (Langner and Siegert, 2009), which most likely explains the higher burnt area recorded by the RSS data set compared to the GFED4 data set in 1997. The AVHRR sensor records data in Borneo twice a day but is saturated at low temperatures and sun glint, leading frequently to false alarms. While the spatial accuracy of the ATSR sensor is high and there are few false alarms due to night-time acquisition, it displays a high rate of omission because fire activity often peaks in the afternoon and the revisit cycle is only every 3 days.

\subsection{Influence of land use and land cover change and peat drainage}

The southern region of Kalimantan has undergone extensive drainage of peatlands and widespread fire-induced loss of pristine forests due to logging activities and plantation establishment, as discussed above. This has created large tracts of forest that are highly degraded and fragmented (Siegert et al., 2001; Langer et al., 2007; Langner and Siegert, 2009; Hoscilo et al., 2011). Future increases in the extent of degraded forests and drained peats will likely modify seasonal rainfall-burnt area relationships. Degraded forests respond more rapidly to rainfall deficits than undisturbed forests due to increased solar radiation reaching the surface and hence higher evaporation rates; they provide a relatively greater source of flammable fuels for burning, such as invasive grasses and ferns as well as debris from logging and land clearing operations (Siegert et al., 2001; Langer et al., 2007; Langner and Siegert, 2009; Hoscilo et al., 2011). The moisture content of peats is controlled by the water table, and as previously discussed, the lower water table of drained peats means more dry peat available for burning than undisturbed peats (Field and Shen, 2008; Page et al., 2011; Hooijer et al., 2012). An increase in the availability of drier fuels from degraded forests and drained peats would therefore potentially increase the amount of burning beyond that forecasted by seasonal rainfall alone. This could be manifested as an increase in the rate of change in burnt area with respect to a unit decrease in rainfall and/or a higher rainfall threshold controlling fire activity.

\section{Conclusions}

While operational seasonal fire prediction over Indonesia will have to incorporate the above factors, we have demonstrated, for the first time, that severe fire events (and potentially associated haze) are fundamentally predictable months in advance using state-of-the art seasonal rainfall forecasts. Predictions are not perfect and occasionally a year may turn out differently to what was expected, fundamentally because ENSO and other factors are not perfectly predictable but also because of remaining model imperfections. Any operational 
forecasting system needs to take account of such uncertainties, for example by use of ensemble methods. Nonetheless, seasonal forecasts are expected to continue to improve in the future and additional post-processing may increase the skill of the fire forecast (Peng et al., 2014). Given the considerable effort required in mobilising prevention and preparedness measures in Indonesia, we therefore argue that seasonal precipitation forecasts should be central to Indonesia's evolving fire-management policies. Other potential applications of seasonal fire forecasting include improved risk assessments of biodiversity and carbon losses through fire; both are important considerations for tropical forest protection programmes (e.g. REDD+; Barlow et al., 2012) and forest (re)insurance enterprises (Cottle, 2007).

Acknowledgements. A. Spessa appreciates funding support provided by the Open University Research Investment Fellowship scheme. The original impetus for this study was enabled through funding from the NERC QUEST programme (FireMAFS: Fire Modelling and Forecasting System project; NE/F001681/1). The work by ECMWF was partially funded by the Copernicus program (http://www.copernicus.eu/). J. Kaiser was supported by the EU FP7 project MACC-II (grant agreement 283576).

Edited by: R. Lasaponara

Reviewed by: two anonymous referees

\section{References}

Adler, R. F., Huffman, G. J., Bolvin, D. T., Curtis, S., and Nelkin, E. J.: Tropical rainfall distributions determined using TRMM combined withother satellite and rain gauge information, J. Appl. Meteorol., 39, 2007-2023, 2000.

Adler, R. F., Huffman, G. J., Chang, A., Ferraro, R., Xie, P. P., Janowiak, J., Rudolf, B., Schneider, U., Curtis, S., Bolvin, D., Gruber, A., Susskind, J., Arkin, P., and Nelkin, E.: The version2 global precipitation climatology project (GPCP) monthly precipitation analysis (1979-present), J. Hydrometeorol., 4, 11471167, 2003.

Aldrian, E. and Dwi Susanto, R.: Identification of three dominant rainfall regions within Indonesia and their relationship to sea surface temperature, Int. J. Climatol., 23, 1435-1452, 2003.

Aragao, L. E. O., Malhi, Y., Barbier, N., Lima, A., Shimabukuro, Y., Anderson, L., and Saatchi, S.: Interactions between rainfall, deforestation and fires during recent years in the Brazilian Amazonia, Philos. T. R. Soc. B, 363, 1779-1785, 2008.

Armenteras-Pascual, D., Retana-Alumbreros, J., Molowny-Horas, R., Roman-Cuesta, R. M., Gonzalez-Alonso, F., and MoralesRivas, M.: Characterising fire spatial pattern interactions with climate and vegetation in Colombia, Agr. Forest Meteorol., 151, 279-289, 2011.

Barlow, J., Parry, L., Gardner, T. A., Ferreira, J., Aragão, L. E., Carmenta, R., and Cochrane, M. A.: The critical importance of considering fire in REDD+ programs, Biol. Conserv., 154, 1-8, 2012.
Burgan, R. E.: Revisions to the 1978 National Fire-Danger Rating System. USDA Forest Service, Southeastern Forest Experiment Station, Research Paper SE-273, 1988.

Chen, Y., Randerson, J. T., Morton, D. C., DeFries, R. S., Collatz, G. J., Kasibhatla, P. S., Giglio, L., Jin, Y., and Malier, M. E.: Forecasting fire season severity in South America using sea surface temperature anomalies, Science, 334, 787-791, 2011.

Cohen, J. D. and Deeming, J. E.: The National Fire Danger Rating System: Basic Equations. USDA Forest Service Pacific Southwest Forest and Range Experimental Station, General Techincal Report PSW-82, 16 pp., 1985.

Cottle, P.: Insuring Southeast Asian commercial forests: Fire risk analysis and the potential for use of data in risk pricing and reduction of forest fire risk, Mitigation and Adaptation Strategies for Global Change, 12, 181-201, 2007.

Dee, D. P., Uppala, S. M., Simmons, A. J., Berrisford, P., Poli, P., Kobayashi, S., and Vitart, F.: The ERA-Interim reanalysis: Configuration and performance of the data assimilation system, Q. J. Roy. Meteor. Soc., 137, 553-597, 2011.

DeFries, R. S., Hansen, M. C., and Townshend, J. R. G.: Global continuous fields of vegetation characteristics: a linear mixture model applied to multi-year $8 \mathrm{~km}$ AVHRR data, Int. J. Remote Sens., 21, 1389-1414, 2000.

Doblas-Reyes, F. J., García-Serrano, J., Lienert, F., Biescas, A. P., and Rodrigues, L. R.: Seasonal climate predictability and forecasting: status and prospects, Wiley Interdisciplinary Reviews: Climate Change, 4, 245-268, 2013.

Field, R. D. and Shen, S. S. P.: Predictability of carbon emissions from biomass burning in Indonesia from 1997 to 2006, J. Geophys. Res.-Biogeo., 113, G04024, doi:10.1029/2008JG000694, 2008.

Field, R. D., Wang, Y., and Roswintiarti, O.: A drought-based predictor of recent haze events in western Indonesia, Atmos. Environ., 38, 1869-1878, 2004.

Field, R. D., van der Werf, G. R., and Shen, S. S. P.: Human amplification of drought-induced biomass burning in Indonesia since 1960, Nat. Geosci., 2, 185-188, 2009.

Fuller, D. O. and Murphy, K.: The ENSO-fire dynamic in insular Southeast Asia, Climatic Change, 74, 435-455, 2006.

Giglio, L., Randerson, J. T., van der Werf, G. R., Kasibhatla, P. S., Collatz, G. J., Morton, D. C., and DeFries, R. S.: Assessing variability and long-term trends in burned area by merging multiple satellite fire products, Biogeosciences, 7, 1171-1186, doi:10.5194/bg-7-1171-2010, 2010.

Giglio, L., Randerson, J. T., and Werf, G. R.: Analysis of daily, monthly, and annual burned area using the fourth-generation global fire emissions database (GFED4), J. Geophys. Res.Biogeo., 118, 317-328, 2013.

Hansen, J. W., Mason, S. J., Sun, L., and Tall, A.: Review of seasonal climate forecasting for agriculture in sub-Saharan Africa, Exp. Agr., 47, 205-240, 2011.

Hooijer, A., Page, S., Jauhiainen, J., Lee, W. A., Lu, X. X., Idris, A., and Anshari, G.: Subsidence and carbon loss in drained tropical peatlands, Biogeosciences, 9, 1053-1071, doi:10.5194/bg-91053-2012, 2012.

Hoscilo, A., Page, S. E., Tansey, K. J., and Rieley, J. O.:Effect of repeated fires on land-cover change on peatland in southern Central Kalimantan, Indonesia, from 1973 to 2005, Int. J. Wildland Fire, 20, 578-588, 2011. 
Huffman, G. J., Adler, R. F., Bolvin, D. T., and Gu, G.: Improving the global precipitation record: GPCP version 2.1, Geophys. Res. Lett., 36, L17808, doi:10.1029/2009GL040000, 2009.

Jones, A. E. and Morse, A. P.: Application and validation of a seasonal ensemble prediction system using a dynamic malaria model, J. Climate, 23, 4202-4215, 2010.

Jones, A. E. and Morse, A. P.: Skill of ENSEMBLES seasonal reforecasts for malaria prediction in West Africa, Geophys. Res. Lett., 39, 23707, doi:10.1029/2012GL054040, 2012.

Langner, A. and Siegert, F.: Spatiotemporal fire occurrence in Borneo over a period of 10 years, Glob. Change Biol., 15, 48-62, 2009.

Langner, A., Miettinen, J., and Siegert, F.: Land cover change 20022005 in Borneo and the role of fire derived from MODIS imagery, Glob. Change Biol., 13, 2329-2340, 2007.

Lass, W., Haas, A., Hinkel, J., and Jaeger, C.: Avoiding the avoidable: towards a European heat waves risk governance, International Journal of Disaster Risk Science, 2, 1-14, 2011.

Lass, W., Haas, A., Hinkel, J., and Jaeger, C.: Avoiding the avoidable: Towards a European heat waves risk governance, in: Integrated Risk Governance, Springer, Berlin, Heidelberg, 119-144, 2013.

Lavers, D., Luo, L., and Wood, E. F.: A multiple model assessment of seasonal climate forecast skill for applications, Geophys. Res. Lett., 36, L23711, doi:10.1029/2009GL041365, 2009.

Margono, B. A., Potapov, P. V., Turubanova, S., Stolle, F., and Hansen, M. C.: Primary forest cover loss in Indonesia over 20002012, Nat. Clim. Change, 4, 730-735, 2014.

McInerney, D., San-Miguel-Ayanz, J., Corti, P., Whitmore, C., Giovando, C., and Camia, A.: Design and Function of the European Forest Fire Information System, Photogramm. Eng. Rem. S., 79, 965-973, 2013.

Miettinen, J., Langner, A., and Siegert, F.: Burnt area estimation for the year 2005 in Borneo using multi-resolution satellite imagery, Int. J. Wildland Fire, 16, 45-53, 2007.

Miettinen, J., Shi, C., and Liew, S. C.: Deforestation rates in insular Southeast Asia between 2000 and 2010, Glob. Change Biol., 17, 2261-2270, 2011.

Molteni, F., Stockdale, T., Balmaseda, M., Balsamo, G., Buizza, R., Ferranti, L., and Vitart, F.: The new ECMWF seasonal forecast system (System 4), p. 49, European Centre for Medium-Range Weather Forecasts, 2011.

Nassar, R., Logan, J. A., Megretskaia, I. A., Murray, L. T., Zhang, L., and Jones, D. B. A.: Analysis of tropical tropospheric ozone, carbon monoxide, and water vapor during the 2006 El Niño using TES observations and the GEOS-Chem model, J. Geophys. Res., 114, D17304, doi:10.1029/2009JD011760, 2009.

Page, S. E., Siegert, F., Rieley, J. O., Boehm, H. D. V., Jaya, A., and Limin, S.: The amount of carbon released from peat and forest fires in Indonesia during 1997, Nature, 420, 61-65, 2002.

Page, S. E., Rieley, J. O., and Banks, C. J.: Global and regional importance of the tropical peatland carbon pool, Glob. Change Biol., 17, 798-818, 2011.

Pappenberger, F., Stephens, E., Thielen, J., Salamon, P., Demeritt, D., Andel, S. J., and Alfieri, L.: Visualizing probabilistic flood forecast information: expert preferences and perceptions of best practice in uncertainty communication, Hydrol. Process., 27, 132-146, 2013
Pappenberger, F., Wetterhall, F., Dutra, E., and Cloke, H. L.: Seamless forecasting of extreme events on a global scale. Climate and Land Surface Changes in Hydrology, edited by: Boegh, E., Blyth, E., Hannah, DM, Hisdal, H., Kunstmann, H., Su, B., and Yilmaz, KK, IAHS Publication, Gothenburg, Sweden, 3-10, 2013.

Peng, Z., Wang, Q. J., Bennett, J. C., Schepen, A., Pappenberger, F., Pokhrel, P., and Wang, Z.: Statistical calibration and bridging of ECMWF System4 outputs for forecasting seasonal precipitation over China, J. Geophys. Res.-Atmos., 119, 7116-7135, doi:10.1002/2013JD021162, 2014.

Reid, J. S., Xian, P., Hyer, E. J., Flatau, M. K., Ramirez, E. M., Turk, F. J., Sampson, C. R., Zhang, C., Fukada, E. M., and Maloney, E. D.: Multi-scale meteorological conceptual analysis of observed active fire hotspot activity and smoke optical depth in the Maritime Continent, Atmos. Chem. Phys., 12, 2117-2147, doi:10.5194/acp-12-2117-2012, 2012.

Roads, J., Fujioka, F., Chen, S., and Burgan, R.: Seasonal fire danger forecasts for the USA, Int. J. Wildland Fire, 14, 1-18, doi:10.1071/WF03052, 2005.

Roads, J., Tripp, P., Juang, H., Wang, J., Fujioka, F., and Chen, S.: NCEP-ECPC monthly to seasonal US fire danger forecasts, Int. J. Wildland Fire, 19, 399-414, 2010.

Roy, D. P., Boschetti, L., Justice, C. O., and Ju, J.: The collection 5 MODIS burned area product - Global evaluation by comparison with the MODIS active fire product, Remote Sens. Environ., 112, 3690-3707, 2008.

Saatchi, S. S., Harris, N. L., Brown, S., Lefsky, M., Mitchard, E. T., Salas, W., and Morel, A.: Benchmark map of forest carbon stocks in tropical regions across three continents, P. Natl. Acad. Sci., 108, 9899-9904, 2011.

Saha, S., Nadiga, S., Thiaw, C., Wang, J., Wang, W., Zhang, Q., and Xie, P.: The NCEP climate forecast system, J. Climate, 19, 3483-3517, 2006.

Saha, S., Moorthi, S., Wu, X., Wang, J., Nadiga, S., Tripp, P., and Becker, E.: The NCEP climate forecast system version 2, J. Climate, 27, 2185-2208, 2014.

Siegert, F., Ruecker, G., Hinrichs, A., and Hoffmann, A. A.: Increased damage from fires in logged forests during droughts caused by El Nino, Nature, 414, 437-440, 2001.

Schultz, M. G., Heil, A., Hoelzemann, J. J., Spessa, A., Thonicke, K., Goldammer, J. G., and van Het Bolscher, M.: Global wildland fire emissions from 1960 to 2000, Global Biogeochem. Cy., 22, GB2002, doi:10.1029/2007GB003031, 2008.

Sudiana, D., Kuze, H., Takeuchi, N., and Burgan, R. E.: Assessing forest fire potential in Kalimantan Island, Indonesia, using satellite and surface weather data, Int. J. Wildland Fire, 12, 175-184, 2003.

van der Werf, G. R., Dempewolf, J., Trigg, S. N., Randerson, J. T., Kasibhatla, P. S., Giglio, L., and DeFries, R. S.: Climate regulation of fire emissions and deforestation in equatorial Asia, P. Natl. Acad. Sci., 105, 20350-20355, 2008.

van der Werf, G. R., Randerson, J. T., Giglio, L., Collatz, G. J., Mu, M., Kasibhatla, P. S., Morton, D. C., DeFries, R. S., Jin, Y., and van Leeuwen, T. T.: Global fire emissions and the contribution of deforestation, savanna, forest, agricultural, and peat fires (19972009), Atmos. Chem. Phys., 10, 11707-11735, doi:10.5194/acp10-11707-2010, 2010.

van Oldenborgh, J. G., Balmaseda, M. A., Ferranti, L., Stockdale, T. N., and Anderson, D. L.: Did the ECMWF seasonal forecast 
model outperform statistical ENSO forecast models over the last 15 years?, J. Climate, 18, 3240-3249, 2005.

Wang, Y., Field, R. D., and Roswintiarti, O.: Trends in atmospheric haze induced by peat fires in Sumatra Island, Indonesia and El Niño phenomenon from 1973 to 2003. Geophys. Res. Lett., 31, L04103, doi:10.1029/2003GL018853, 2004.
Wooster, M. J., Perry, G. L. W., and Zoumas, A.: Fire, drought and El Niño relationships on Borneo (Southeast Asia) in the pre-MODIS era (1980-2000), Biogeosciences, 9, 317-340, doi:10.5194/bg-9-317-2012, 2012. 